\title{
SLC22A3 wt Allele
}

National Cancer Institute

\section{Source}

National Cancer Institute. SLC22A3 wt Allele. NCI Thesaurus. Code C113562.

Human SLC22A3 wild-type allele is located in the vicinity of $6 q 25.3$ and is approximately $107 \mathrm{~kb}$ in length. This allele, which encodes Solute carrier family 22 member 3 protein, plays a role in the disposition of cationic neurotoxins and neurotransmitters in the brain. Mutations in this gene are associated with extragonadal seminoma and placental choriocarcinoma. 